مجلة دراسات في المناهج وطرق التدريس، الترقيم الاولي (ISSN 2535-213X)/ العدد 243 (2019م)

\title{
General Secondary Certificate English Language Scores as a Predictor of Prospective Pharmacists' EFL Achievement
}

\author{
Adel I. El-Banna and Marwa A. Naeem ${ }^{1}$ \\ Faculty of Education, Kafr El-Sheikh University, Kafr El-Sheikh, 2019
}

\begin{abstract}
Aiming at investigating the predictive power of the Egyptian General Secondary Certificate (GSC) official English exam scores and their relation to EFL achievement at university, the researchers analyzed the scores for a large sample of 234 pharmacist freshmen. Moreover, gender differences were also examined. Three hypotheses were posed for the quest. Data were collected from the GSC official exam as well as the freshmen's college exam. In terms of statistics, simple linear regression was used to analyze data and find the predictive relation between the variables. Results unearthed that GSC official English exam scores had a significant power as a predictor of EFL freshmen's college achievement in English. It was also found that there were gender differences for females' sake in this concern. Consequently, the researchers provided some recommendations for developing the GSC exam and improving male students' performance. Keywords: testing, achievement, predictive power, gender differences.
\end{abstract}

\footnotetext{
${ }^{1}$ Author Note

Adel Ibrahim El-Banna, Department of Curriculum and Instruction, Faculty of Education, Kafr El-Sheikh University; Marwa Ahmed Naeem, Department of Curriculum and Instruction, Faculty of Education, Kafr El-Sheikh University.

Correspondence concerning this paper should be addressed to Marwa Naeem, E-mail: marwa.naem@edu.kfs.edu.eg
} 


\section{درجات امتحان الثهادة الثانوية العامة كمنبى لتحصيل طلاب كلية الصيلنة للغة الإنجليزية كلغة أجنبية}

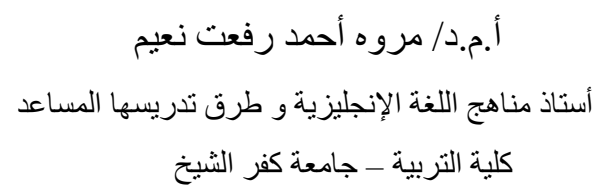

\section{مُسنَخلَه}

هدفت الدراسة إلى استقصاء القوة التنبؤية لدرجات الاختبار الرسمى لثهادة إتمام الثانوية العامة و علاقتها بتحصيل اللغة الإنجليزية كلغة أجنبية لاى طلاب الجامعة؛ ولذا قام الباحثان بتحليل درجات عينة كبيرة بلغت

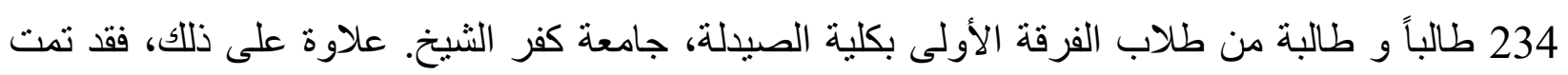

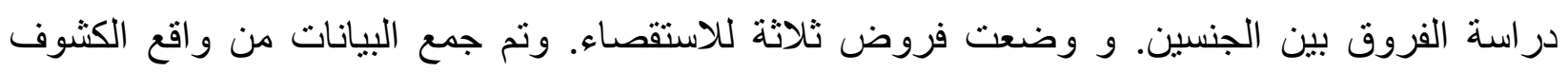

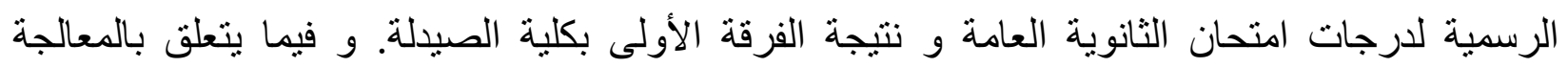
الإحصائية، تم استخدام الانحدار الخطى البسيط لتحليل البيانات و إيجاد العلاقة التنبؤية بين المتغيرات. و و قد كثفت النتائج عن القوة التنبؤية الملحوظة لامتحان شهادة الثانوية العامة فيما يتعلق بتحصيل طلاب الفرقة

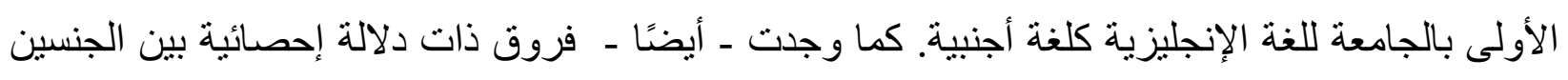
لصالح الإناث فى ذالك الخصوص. و بناءً عليه، قام الباحثان بتقديم مجموعة من التوصيات بشأن تطوير

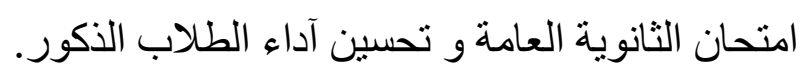
الكلمات المفتاحية:الاختبار، التحصيل، القوة التنبؤية، الفروق بين الجنسين. 


\section{General Secondary Certificate English Language Scores as a Predictor of}

\section{Prospective Pharmacists' EFL Achievement: A Correlational Study ${ }^{(*)}$}

The General Secondary Certificate (GSC) scores are the only determinant upon which joining a certain faculty in Egypt is decided. Accepting or rejecting freshmen into a certain language program or a field of specialization depends on their GSC scores at a specific language. However, GSC exams are not academically prepared in the sense that their validity, reliability and worthiness are not confirmed by examiners. Consequently, relying on GSC scores as a sole means to predict a student's aptitude to study an intended program is questioned.

Academic achievement was generally defined as the scores on a specific test. It was restricted to grades, attendance and behavioural compliance (Eldon, 2015). Grant and Stronge (2013) defined achievement as a type of assessment whose design was made for the priority that it measured how much knowledge and skills learners attained after studying a certain course or program.

A relevant study aimed at identifying three categories of predictors; namely, cognitive, motivational and behavioural predictors of two measures of university students' achievement: grade point average and student efficacy status. Participants were 250 undergraduates who had been followed for three years. The contribution of the variables under study was statistically treated through hierarchical regression and logistic regression analyses. Fear of disappointing parents, time and study environment were pronounced as the most influencing predictors for both measures. Outcome expectation was a significant predictor of the students' efficacy

\footnotetext{
${ }^{(*)}$ This research work is written according to the American Psychological Association (APA), Sixth Edition Publication Manual.
} 
status only. Besides, beliefs and goal orientations were significant predictors only of the GPA. It was

concluded that agreeableness, extraversion, openness and academic adjustment played an even more prominent role in university students' academic achievement. These variables were recommended for investigation in further research work (Bećirević, Ažić \& Dorčić, 2017).

In the same year, Manzouri and Movahed (2017) explored the general tendencies of emotional intelligence and language anxiety among Iranian EFL learners. They also attempted to find correlation among these tendencies and learners' achievement as well as their self-rated proficiency. Participants were eighty two Iranian EFL learners randomly selected. The study had two tools: a Foreign Language Classroom Anxiety Scale (FLCAS) and a Trait Emotional Intelligence Questionnaire-Short Form (TEIQue-SF). Participants were asked to self-rate their own English proficiency. Besides, they took a General English achievement test. In terms of achievement, results revealed that emotional intelligence was found to be significantly correlated with achievement and selfrated proficiency.

Adopting the idea that language was affected by a variety of factors, Afshar, Tofighi and Hamazavi (2016) investigated relationships among emotional intelligence, learning style, language learning strategy use and the L2 achievement of Iranian EFL learners. Participants in the study were one hundred and thirty eight Iranian EFL learners. The tools used to collect data were three ready-made Likertscale questionnaires; namely: the Emotional Quotient Inventory, the Learning Style Questionnaire and the Strategy Inventory for Language Learning. Achievement was represented in the averages of participants' final scores in the 
مجلة دراسات في المناهج وطرق التدريس، الترقيم الدولي (ISSN 2535-213X)/ العدد 243 (2019م)

previous four terms. In terms of statistics, Pearson correlation was used. Findings revealed that there was no statistically significant relationship between learning styles and L2 achievement. However, strategy use and emotional intelligence were stronger predictors of L2 achievement. Furthermore, the findings indicated that assertiveness, as a component of emotional intelligence, was the best predictor of L2 achievement.

Another closely-related study was made by Thatha and Almshayikh (2016). They tried to find whether Foreign High School Averages for foreign programs (American, British and Swiss) and Jordanian General Secondary Education Average (GSEA) could be used as criteria for university entrance or not. Their massive sample was 89748 students who graduated from five Public Universities. Statistically, they used simple linear regression and hierarchical multiple regression to compare averages and identify their predictive ability. It was concluded that Jordanian (GSEA) had a weak predictive ability of $13.4 \%$. The factors of gender, family and study branch were found to have significant impacts on the analyzed averages.

Lerner and Jovanovic (2016) handled the idea that academic achievement was not affected by puberty; rather, it was affected by such contextual factors as transition to another school, family social status and cultural beliefs. Consequently, they highlighted the importance of developing adolescents' academic achievement through a multi-level perspective that took into account the interaction between a youth's personal traits and his context.

Concentrating on social factors, Donlan, Prescott and Zaff (2016) analyzed the diverse contexts within which adolescents graduate from high school and enroll in college. The data of a massive sample of 7100 were collected and examined. 
Statistically, they used weighted logistic regression analyses controlling such variables as gender, unemployment, race and income. They reached the conclusion that youth could overcome the challenges associated with community poverty and achieve academically in low and medium levels of poverty. However, in highpoverty contexts, more resources might be needed to reach higher levels of academic achievement.

$\mathrm{Yu}, \mathrm{Li}$ and Destech (2016) focused on gender differences in technology-aided flipped classroom. Clickers were used to facilitate students' response and interaction to assignments, quizzes and discussions. Scales of satisfaction and academic achievements among EFL learners were used. It was concluded that there were no statistically significant gender differences in satisfaction and academic achievements in the clicker-aided flipped EFL class. Results and directions for future research were discussed.

Investigating the effect of blogs on writing achievement in the Turkish EFL context, Ozdemir and Aydin (2015) made a study on 40 EFL learners. The instruments of their study included a background questionnaire and a writing achievement pre-posttest. They came to the conclusion that blogging itself did not affect writing achievement. However, the process-based writing instruction positively affected learners' achievement in both traditional and blog environments. Teachers were advised to be aware that the use of blogs did not guarantee better writing achievement among Turkish EFL learners. A writing environment in which teachers encourage students to write in the target language should be created to increase writing achievement.

Believing that critical thinking is a crucial prerequisite for college students as it is required for many courses and skills - i.e. writing for EFL learners, Evens, 
Verburgh and Elen (2013) studied the influence of general secondary certificate scores on college freshmen's critical thinking. They stated that a student's secondary education is an important base and a reliable determinant of higher education success. Eight hundred and thirty-one subjects participated in that study. Their critical thinking was measured by the Scipio test which contained both constructed response items and forced choice items. Findings referred to a small growth of freshmen's critical thinking in average. However, students with high general secondary scores academically outperformed their peers. Moreover, it was concluded that critical thinking shapes students' educational choices when they join higher education programs.

Attempting to evaluate the predictors of academic performance, Moreira, Dias, Vaz and Vaz (2013) integrated educational persistence, motivational, and study skills indicators. Moreover, they combined approaches centered on the variables and those centered on the person. Participants in their study were 384 Portuguese secondary school students. They found that there were five factors that could predict achievement: socio-economic status, parental involvement, academic goals, student-teacher interaction and academic-related skills. A recommendation of integrating academic related skills, indicators of educational persistence theories and indicators of motivational models in secondary school students was suggested. Furthermore, multidimensional models of students' engagement with school were preferred in analyzing academic achievement.

In their two-fold purpose study, Abdolrezapour and Tavakoli (2012) investigated the possibility of enhancing emotional intelligence through prepared literature response activities, and tried to find if there was a relationship between emotional intelligence and EFL learners' reading comprehension achievement. The 
sample for their study included 63 Iranian students studying Interchange 2 course in a language center. Two tools were used: a thirty-item reading comprehension test and the Trait Emotional Intelligence Questionnaire-Adolescent Short Form (TEIQue-ASF). The experiment based on providing the experimental group students with some pieces of literary work including short stories with highly emotional content encouraging them to talk about their emotions and raising their emotional intelligence. Findings referred to greater achievement for the sake of the control group in both reading comprehension achievement and TEIQue-ASF. Significant implications for EFL teachers and practitioners were highlighted.

Realizing the fact that the factors that affect learners' progress were crucial for educators, Kelsen and Liang (2012) attempted to estimate the indicators of success in the context of student achievement in university EFL courses in Taiwan. They collected data from two classes of sophomores. Assessment aspects that served as dependent variables contained overall final grade, final exam score, oral test performance and scores received on the listening, reading, and writing sections of the final exam. In terms of statistics, Pearson product-moment correlations and stepwise multiple regression analyses were employed. Multiple regressions using the selected variables suggested that hours spent studying English, participation in the English taught program, first language ability, attendance and reading for pleasure were the most significant indicators of achievement. All models provided statistically significant moderate to strong explanatory power. Pedagogical considerations based on the results were recommended and suggestions for further research were provided.

Focusing on achievement at high schools, Gordon, Bridglall and Meroe (2005) attracted attention to the fact that most public high schools need improvement. 
They noted that there was an obvious decrease at academic achievement for many high school students. Innovation in teaching methods and assessment techniques and the necessity of change were advocated to narrow the gap between low and high achievers.

The related studies presented above rendered controversial results. While some studies recommended high school scores as a good predictor of university students' achievement, other studies either negated high school scores predictive power, or highlighted other factors as strong predictors of undergraduates' achievement. This controversy justified conducting the current study so as to fill in a gap among its predecessors.

Consequently, the problem of the current study can be elucidated in the need of questioning the only accredited criterion of accepting students in the different Egyptian faculties. That is to say that the predictive power of GSC scores, as a prerequisite that guarantees a university student's aptitude to study a certain specialized field, ought to be tested.

\section{Hypotheses}

Delimiting the study problem, the researchers formulated the following testable null hypotheses:

1 - There is no predictive relationship between male prospective pharmacists'

G.S.C. total score and their English college achievement score.

2 - There is no predictive relationship between prospective female pharmacists'

G.S.C. total score and their English college achievement score

3 - There is no predictive relationship between prospective pharmacists' G.S.C. total score and their English college achievement score. 


\section{Method}

\section{Participants}

Two hundred and thirty four pharmacist freshmen: 141 males and 93 females participated in the study at hand. Their average age was nineteen years old. They have been studying English for twelve years as a Foreign Language. According to the standards set by the National Center of Education Statistics in Snyder, Brey and Dillow (2019), all participants are high achievers as their G.S.C. English score percentages ranged from $87 \%$ and $100 \%$. In terms of specialization, participants had a scientific background as they were students at the scientific branch of the secondary stage. The content of the courses they had studied throughout the secondary stage covered miscellaneous topics: scientific and literary.

\section{Tools}

Data for this study were collected by two tools: the official English G.S.C scores and an ESP college achievement test. The achievement test consisted of three sections. In the first section, participants were asked to write as much as they could on one only of two topics: Social Effects of Drug Abuse or Herbal Alternative Medicine. Both topics were related to participants' area of specialization. The second section included reading comprehension questions based on reading passages related to participants' specialty, too. The last section was devoted to translation. Participants were given two passages in English; one on marketing principles used in the pharmaceutical industry and the other on pharmacology. Test reliability was calculated by finding Cronbach's Alpha using PASW Statistics 18 software (2009). The obtained value equaled .72. This value is considered adequate for establishing test reliability according to Biddle (2006). For validation, the test was face and content validated by some experts in the field of 
curriculum language teaching and testing. Moreover, the test was intrinsically validated by calculating the root square of reliability index. Thus, its intrinsic validity equaled .85. According to El-Sayed (1979), this obtained value proved that the achievement test is a valid tool.

\section{Procedure}

A descriptive analytical method was employed in the current research work. Participants' scores in the G.S.C. official exam and their scores on the college English achievement test were statistically analyzed. Simple linear regression was adopted to determine the predictive power of G.S.C. scores in relation to college achievement in English.

\section{Results}

The two hypotheses of the study were statistically tested by linear simple regression. This technique aimed at determining the existence of a predictive relationship between variables. PASW Statistics 18 software (2009) was used to analyze data. The following results were attained:

\section{Hypothesis One}

The researchers hypothesized that there is no predictive relationship between male prospective pharmacists' G.S.C. total score and their English college achievement score. The following table shows the obtained results:

Table 1

Simple Linear Regression for Male Prospective Pharmacists' G.S.C and Achievement Scores

\begin{tabular}{|c|c|c|c|c|c|c|c|c|}
\hline $\begin{array}{c}\text { Independent } \\
\text { Variable(s) }\end{array}$ & $\begin{array}{c}\text { Dependent } \\
\text { Variable }\end{array}$ & $\mathrm{B}$ & Beta & $\begin{array}{c}\text { Standard } \\
\text { Error }\end{array}$ & $\mathrm{t}$ & $\mathrm{R}^{2}$ & $\mathrm{~F}$ & Significance \\
\hline $\begin{array}{c}\text { Males' } \\
\text { G.S.C }\end{array}$ & $\begin{array}{c}\text { Males' } \\
\text { Achievement }\end{array}$ & 0.41 & 0.05 & 0.86 & 0.48 & 0.003 & 0.23 & 0.63 \\
\hline
\end{tabular}


For male participants, the determination coefficient equaled 0.003 and $\mathrm{F}$ was 0.23 . The significance of these values was 0.63 . Since the significance is greater than 0.05 , it can be concluded that prospective male pharmacists' G.S.C. score is not a reliable predictive tool for their college achievement in English.

\section{Hypothesis Two}

The second hypothesis assumed that there is no predictive relationship between female prospective pharmacists' G.S.C. total score and their English college achievement score. Statistical analysis of data rendered the following results:

Table 2

Simple Linear Regression for Female Prospective Pharmacists' G.S.C and Achievement Scores

\begin{tabular}{|c|c|c|c|c|c|c|c|c|}
\hline $\begin{array}{c}\text { Independent } \\
\text { Variable(s) }\end{array}$ & $\begin{array}{c}\text { Dependent } \\
\text { Variable }\end{array}$ & $\mathrm{B}$ & Beta & $\begin{array}{c}\text { Standard } \\
\text { Error }\end{array}$ & $\mathrm{t}$ & $\mathrm{R}^{2}$ & $\mathrm{~F}$ & Significance \\
\hline $\begin{array}{c}\text { Females' } \\
\text { G.S.C }\end{array}$ & $\begin{array}{c}\text { Females' } \\
\text { Achievement }\end{array}$ & 1.84 & 0.27 & 0.55 & 3.37 & 0.075 & 11.33 & 0.001 \\
\hline
\end{tabular}

The determination coefficient equaled 0.075 and $\mathrm{F}$ was 11.33. The significance of these values was 0.001 . Since the significance is less than 0.05 , it can be concluded that prospective female pharmacists' G.S.C. score is a reliable predictive tool for their college achievement in English.

\section{Hypothesis Three}

Devoted to the whole sample, the third hypothesis was formulated as follows: There is no predictive relationship between prospective pharmacists' G.S.C. total score and their English college achievement score. The following table shows the obtained results: 
Table 3

Simple Linear Regression for Prospective Pharmacists' G.S.C and Achievement Scores

\begin{tabular}{|c|c|c|c|c|c|c|c|c|}
\hline $\begin{array}{c}\text { Independent } \\
\text { Variable(s) }\end{array}$ & $\begin{array}{c}\text { Dependent } \\
\text { Variable }\end{array}$ & $\mathrm{B}$ & Beta & $\begin{array}{c}\text { Standard } \\
\text { Error }\end{array}$ & $\mathrm{t}$ & $\mathrm{R}^{2}$ & $\mathrm{~F}$ & Significance \\
\hline G.S.C & Achievement & 1.33 & 0.18 & 0.47 & 2.80 & 0.033 & 7.85 & 0.006 \\
\hline
\end{tabular}

The above table showed that the determination coefficient equaled 0.033 and $\mathrm{F}$ was 7.85 . The significance of these values was 0.006 . Since the significance is less than 0.05 , it can be concluded that prospective pharmacists' G.S.C. score is a reliable predictive tool for their college achievement in English.

\section{Discussion}

Investigating the predictive power of G.S.C score in English and its relation to EFL prospective pharmacists rendered varied results. Gender differences were shown up. Male prospective pharmacists' G.S.C. scores turned out to be an unreliable predictive tool of their college achievement of English. However, G.S.C. scores were predictive of female prospective pharmacists' college achievement scores. The researchers attempted to discuss these results in the light of language learning theories, related studies and their own observations and deductions.

Negating the role of gender differences in reading achievement; Phillips, Loerke and Hayward (2018) believed that other factors - that did not include gender - affected reading achievement. Such factors were motivation, amount read and reading comprehension. Therefore, they considered the idea of males' underachievement in reading as meretricious.

However; Reilly, Neumann and Andrews (2018) confirmed that female students outperformed boys in reading and writing achievement in all grades. Typically, females scored significantly higher on spelling and grammar standardized tests. Educationally, they provided a number of beneficial 
implications. Teachers should be cautious on assigning literary material as external reading activities. Such activities would represent impediments for male students. Another educational implication was that the format of examination might be a contributing factor in gender differences on standardized test achievement.

On the same track, Yand and Quadir (2018) also concluded that female students excelled their male peers in a reward-based achievement system that activated gaming. However, males and females had equal motivation towards language learning.

Alrabai (2016) classified the factors that impact Saudi students' EFL achievement into internal factors and external ones. According to his study, gender was one of the internal or individual factors that affected the Saudi achievement of English. He believed that female university students' supremacy in EFL achievement is a pattern in some societies including Saudi Arabia. Alarabi also listed aptitude, age, learning style, attitudes, anxiety, autonomy, learning strategies and motivation among the internal factors influencing EFL achievement. The influence of Arabic as the first language (L1), religion, culture, teacher behavior, teaching styles, curricula, teaching methods, overcrowded classes, lack of teacher training and a lack of adequate technology were also identified as external factors that affected EFL achievement in Saudi Arabia.

Similar results were obtained by Hamdan and Al-Hattami (2016). They concluded that high school GPA score was a valid predictor of college achievement in Saudi Arabia. However, they recommended admission test scores as more valid predictors of college success in medical sector colleges than colleges of humanities and literary specializations. Moreover, gender differences were also 
investigated. It was found that females' college achievement could be determined by their high school scores more than males.

The current results are not consistent with those obtained by Hismanoglu (2016). His conclusions highlighted that male students had more positive beliefs about language learning than female students concerning such components as foreign language aptitude, difficulty of language learning, learning and communication strategies. This contradiction might be attributed to the different age of participants - as Hismanoglu's sample was selected from preparatory stage students. Moreover, this inconsistency proved that motivation and other affective factors may not be parallel with achievement.

A closely related study was made by Thatha and Almshayikh (2016) in Jordan. They found that college achievement could be predicted by General Secondary Certificate Score in general. The gender factor effect was very marginal. They also compared the predictive power of the GSC scores among humanistic college students and medical college ones. Interestingly, results confirmed that GSC scores had a predictive value for medical college students. This result was attributed to the sound criteria upon which language curricula were planned and developed in medical colleges.

In 2015, Broadbent and Poon were interested in comprehending how students could best apply self-regulated learning strategies to achieve academic success within online environments. Positive correlation was found between such strategies as time management, metacognition, effort regulation, and critical thinking on one hand and academic achievement on the other. Female students usually employ such strategies more effectively than their male counterparts. 
In the same year, Opara, Onyekuru and Njoku (2015) investigated the predictive relationship between school based assessment scores and achievement in Junior Secondary Certificate Examination (JSCE) in English. Results confirmed a strong predictive relationship. Therefore, there was a recommendation of encouraging school-based assessments and making them obligatory in such core subjects as English.

General secondary education level was found related to college students' critical thinking. It was important to pay heed to students' choices at secondary education, because those choices determined higher education performance (Evens, Verburgh \& Elen, 2013).

Karthigeyan and Nirmala (2012) unearthed similar results to the current study. They reached the conclusion that girls outperformed boys in in almost all academic and competitive exams. No enough explanations were provided about the reasons for such obvious gender differences. Yet, they gave a noteworthy recommendation as regard increasing males' motivation and training teachers in a special way on bridging the gap between males' and females' achievement.

On the contrary, language factor was not significant in predicting college achievement. Although female students entered college with higher secondary stage scores than male students, gender was depicted as a weak predictor of college first-year language score (Winter \& Dodou, 2011).

The current results were not in harmony with Hyde's (2005) Gender Similarities Hypothesis (GSH) which claimed that most — but not all — gender differences are small or trivial in size. These differences were attributed to statistical errors in both small and large sample sizes. 
The researchers attributed the predictive power of GSC scores to three reasons. First, the sound and organized criteria upon which the GSC English exam is constructed and applied. Second, the components of the English GSC exam were similar to those of the college English achievement exam. Both exams included a writing composition, reading comprehension questions, grammar multiple-choice questions and a translation passage. Third, the relatively short time span between the last year at the secondary stage and the first year at college might guarantee retention.

In regard to gender differences, it was supposed that females' GSC score determined their college achievement, because they tended to be more enthusiastic and ambitious than males. Rather than their male counterparts, female students were more committed to attending lectures, participating orally and delivering assignments in time. This commitment should have been helped them keep their GSC levels in their first year at college. Notwithstanding, further research was recommended to prove such tentative explanations.

\section{Conclusion}

General Secondary Certificate exam has proved to be a reliable predictor of college achievement in English. Hence, it is recommended to pay much attention to English teaching and evaluation at the secondary stage. Revolutionizing secondary stage English curricula is needed to set the basis for a successful college achievement. Testing techniques should also be developed and updated to save much money and effort. The reasons behind male students' lag require meticulous investigation. 


\section{References}

Abdolrezapour, P., \& Tavakoli, M. (2012). The relationship between emotional intelligence and EFL learners' achievement in reading comprehension. Innovation in Language Learning and Teaching, 6(1), 1-13. doi:10.1080/17501229.2010.550686.

Afshar, H. S., Tofighi, S., \& Hamazavi, R. (2016). Iranian EFL learners' emotional intelligence, learning styles, strategy use, and their L2 achievement. Issues in Educational Research, 26(4), 635-652.

Alrabai, F. (2016). Factors underlying low achievement of Saudi EFL learners. International Journal of English Linguistics. 3(6). 1-17.

Bećirević, I., Z., Ažić, S., S., \& Dorčić, T., M. (2017). Predictors of university students' academic achievement: A prospective study. ISTRA, 26(4), 457 476.

Biddle, D. (2006). Adverse impact and test validation: a practitioner's guide to valid and defensible employment testing. Aldershot: Gower Publishing.

Broadbent, J., \& Poon, W. L. (2015). Self-regulated learning strategies \& academic achievement in online higher education learning environments: A systematic review. Internet and Higher Education, 27. 1-13.

Donlan, A., E., Prescott, J., E., \& Zaff, J., F. (2016). Differential predictors of academic achievement: individual and familial factor interactions with community poverty. Journal of Children and Poverty, 22(2), 113 - 132.

Eldon, C. L. (2015). Brainstorming common core: Challenging the way we think about education. Maryland: Rowman \& Littlefield.

El-Sayed, F. A. (1979). Statistical psychology and human mind measurement. Third Ed. Cairo: Dar El-Fikr El-Araby. 
مجلة دراسات في المناهج وطرق التدريس، الترقيم الدولي (ISSN 2535-213X)/ العدد 243 (2019م)

Evens, M., Verburgh, A., \& Elen, J. (2013). Critical thinking in college freshmen: The impact of secondary and higher education. International Journal of Higher Education, 2(3), 139 - 151.

Gordon, E. W., Bridglall, B. L., \& Meroe, A. S. (2005). Supplementary education: the hidden curriculum of high academic achievement. Maryland: Rowman \& Littlefield.

Grant, L., \& Stronge, J. (2013). Student achievement goal setting: Using data to improve teaching and learning. New York: Routledge.

Hamdan, A., \& Al-Hattami, A. (2016). The accuracy of predicting university students' academic success. Retrieved on September 2, 2019 from https://www.researchgate.net/publication/270647067.

Hismanoglu, M. (2016). A study on English preparatory program EFL learners' beliefs about language learning in relation to gender, second foreign language knowledge and foreign country experience. International Journal of Applied Linguistics \& English Literature, 5(5), doi:10.7575/aiac.ijalel.v.5n.5p.109. 109-118.

Hyde, J. S. (2005). The gender similarities hypothesis. American Psychologist, 60, 581-592. http://dx.doi.org/10.1037/0003-066X.60.6.581.

Karthigeyan, K., \& Nirmala, K. (2012). Academic achievement in English: an analysis through gender lens. MIER Journal of Educational Studies, Trends \& Practices, 2(2).144-157

Kelsen, B. A., \& Liang, H. Y. (2012). Indicators of Achievement in EFL Classes at a Taiwanese University. Education Research International, 8. doi:10.1155/2012/635964.

Lerner, R., \& Jovanovic, J. (2016). Cognitive and moral development, academic 
achievement in adolescence. New York: Routledge.

Manzouri, H. A., \& Movahed, R. (2017). Investigation of the relationship among emotional intelligence, foreign language anxiety, language proficiency, and achievement of Iranian EFL learners. Quid-Investigacion Ciencia Y Tecnologia (1), 2464-2472.

Moreira, P., Dias, P., Vaz, F., \& Vaz, J. (2013). Predictors of academic performance and school engagement - Integrating persistence, motivation and study skills perspectives using person-centered and variable-centered approaches. Learning and Individual Differences, 24, 117-125.

Opara, I., M.; Onyekuru, B., U., \& Njoku. J. U. (2015). Predictive power of school based assessment scores on students' achievement in junior secondary certificate examination (JSCE) in English and mathematics. Journal of Education and Practice, 6(9). 112-116.

Ozdemir, E., \& Aydin, S. (2015). The effects of blogging on EFL writing achievement. In: I. H. Mirici, I. H. Erten, \& H. Oz (Eds.), Proceedings of the 1st Globelt Conference on Teaching and Learning English as an Additional Language (Vol. 199, pp. 372-380). Amsterdam: Elsevier Science Bv.

Phillips, L., M.; Loerke, K., \& Hayward, D. V. (2018). The consequential effects of misinterpretations and misrepresentations on boys' and girls' reading achievement and motivation. In: Orellana García P., Baldwin Lind P. (eds) Reading achievement and motivation in boys and girls. Berlin: Springer.

Reilly, D., Neumann, D. L., \& Andrews, G. (2018). Gender differences in reading and writing achievement: Evidence from the national assessment of educational progress (NAEP). American Psychologist. Advance online publication. Retrieved from http://dx.doi.org/10.1037/amp0000356; on 
September 20, 2018.

Snyder, T. D., Brey, C. D., and Dillow, S. A. (2019). Digest of Education Statistics. (NCES 2018-070). National Center for Education Statistics. Washington, DC: Institute of Education Sciences.

Yand, J., C., \& Quadir, B. (2018). Individual differences in an English learning achievement system: gaming flow experience, gender differences and learning motivation. Technology, Pedagogy and Education, 27(3), 351-366, DOI: 10.1080/1475939X.2018.1460618

Yu, Z. G., Li, M., \& Destech P., I. (2016). Gender differences in satisfaction and academic achievements in the clicker-aided flipped EFL class. International Conference on Education and Development (Iced 2016), 242-248.

SPSS Inc. (2009). PASW Statistics for Windows, Version 18.0. Chicago: SPSS Inc.

Thatha, H. I., \& Almshayikh, J. K. (2016). Comparing the predictive ability of the Jordanian general secondary education average (GSEA) and foreign high school averages for Jordanian students with the grade point average (GPAS) at Jordanian public universities. Educational Sciences Studies, 43(2), 637662.

Winter, J., \& Dodou, D. (2011). Predicting academic performance in engineering using high school exam scores. International Journal of Engineering Education, 27(6). 1343-1351. 